\title{
The Effect of Trainee Counseling Psychologists' Self-Efficacy on Interpersonal Relations
}

\author{
Kyeng-my Song ${ }^{1}$, Sung-je $\mathrm{Cho}^{2}$ \\ 2838 Dept. Department of Regional and Welfare Administration Department, \\ Dongbang Culture Graduate Univ., 28 Sungbok-Ro, Sungbokdong, Seoul, Korea \\ 2chosj715@daum.net
}

\begin{abstract}
The purpose of this study is to investigate the difference and the relationship between the self-efficacy of trainee counseling psychologists and their interpersonal relations. The subjects of the study were 166 trainee counseling psychologists in Ulsan Metropolitan City. The SPSS program was used for analysis, including frequency analysis, reliability analysis, correlation analysis, t-test and one-way ANOVA, and multiple regression analysis was conducted on the causality between the variables. The results of the study are as follows: first, upon analyzing the difference in self-efficacy according to the general characteristics of trainee counseling psychologists, there was a significant difference in mean between the groups for self-efficacy according to age and monthly income. Second, for self-efficacy according to the general characteristics of trainee counseling psychologists, there was a significant difference in mean between the groups according to gender and monthly income. Third, self-efficacy perceived by trainee counseling psychologists was found to have a positive effect on interpersonal relations. This study seeks to provide foundational data for the development of programs for trainee counseling psychologists to establish positive interpersonal relations.
\end{abstract}

Keywords: Trainee Counseling Psychologists, Self-Efficacy, Interpersonal Relations

\section{Introduction}

\subsection{Necessity of Research}

As we enter the age of global competition, modern people are under stress from issues that arise from interpersonal relations. The background of such stresses includes conflict with colleagues in the workplace, family problems, conflict with friends, and problems with raising children. All these reasons are related to interpersonal relations, and people are increasingly exposed to mental poverty and psychological pain due to stress or problems with interpersonal relations. The necessity of counseling has emerged to modern people who are suffering from psychological pain. Unlike the past, negative preconceptions have reduced for clients using counseling services, the demand for counseling services is increasing, and counseling is having an important effect on the mental health of the modern people [1]. Therefore, the great importance of the counselor and their role is being recognized.

The factors of a counselor include various characteristics, from the external characteristic of the counselor to more human qualities like their attitude, sincerity and interest. From these, the

Article history:

Received (March 16, 2019), Review Result (May 26, 2019), Accepted (July 15, 2019) 
self-efficacy of the counselor is a factor that is particularly emphasized in the development of early career counselors [2]. Self-efficacy of the counselor is 'the confidence of the counselor that they can effectively counsel their clients' [3], and it is important for the counselor to improve their self-efficacy, particularly in terms of the counselor's counseling outcome. It is especially important for early career counselors to understand how they perceive their selfefficacy, because early career counselors are faced with the difficulty of adapting to new interpersonal relations with clients as they enter the workforce. Therefore, self-efficacy is an important variable for the early career counselor.

A review of existing studies on self-efficacy reveals that the self-compassion of counselors, along with age and counseling experience, was meaningful for the empathy and self-efficacy of the counselor. This result suggests that the more the counselor looked after oneself with selfcompassion, the more they could empathize with their client, and also the higher the selfefficacy of the counselor [4]. In addition, the working alliance perceived by the counselor in the beginning stage of counseling was found to have a significant positive correlation with selfefficacy and a significant negative correlation with state anxiety[5]. For sub-variables of the counselor's self-efficacy that affects counseling satisfaction, detailed counseling technique had meaningful difference as the most influential variable in the case of counselor's counseling satisfaction. In the case of the client's counseling satisfaction, meaningful differences were found in detailed counseling techniques, counseling process and management of challenging client behavior. The self-efficacy of the counselor and working alliance were found to be meaningful variables that affect the client's counseling satisfaction [6]. These results confirm the importance of the counselor's self-efficacy and the formation of amiable interpersonal relations with the client in the counseling and psychological therapy setting.

The authenticity of the counseling directly affects the working alliance reported by the client and simultaneously exerts indirect effects with the counselor's counseling relations techniques and the client's perception of the counselor as an intermediary[7] In addition, the higher the counselor's self-efficacy, the higher the working alliance with the client, which then leads the client to evaluate the counseling session positively, revealing a positive correlation between the working alliance and counseling outcome [8]. Meanwhile, positive automatic thought had a significant positive correlation with working alliance. That is, the more positive thinking by counselors, there were significant positive correlations with the working alliance, and insecure attachment had a significant negative correlation with working alliance [9].

From these results of existing studies emerges the necessity of research on the effect of the self-efficacy of trainee counseling psychologists on their interpersonal relations. Existing studies include counseling case studies for counseling psychologists, but there is very little research on the interpersonal relations of trainee counseling psychologists. Therefore, this study seeks to find the effect of self-efficacy on interpersonal relations for trainee counseling psychologists, in order to provide foundational data for successful counseling outcomes of clients.

\subsection{Research Question}

The purpose of this study is to analyze the difference and relationship with the self-efficacy of trainee counseling psychologists and their interpersonal relations, and the detailed research questions are as follows.

First, how is the difference in self-efficacy according to the general characteristics of trainee counseling psychologists? 
Second, how is the difference in interpersonal relations according to the general characteristics of trainee counseling psychologists?

Third, how does the self-efficacy of trainee counseling psychologists affect interpersonal relations?

\section{Research Method}

\subsection{Reliability}

Upon verifying the reliability of each variable used in this study, self-efficacy had a reliability of .619 and interpersonal relations .675 . The reliability of each measurement tool exceeded the minimum standard Cronbach's $\alpha$ value of .60, securing reliability.

\subsection{Data Processing and Analysis Method}

Data collected for this study was processed and verified using the SPSS 22.0 program at a significance level of 5\%, and the reliability of each measurement tool was analyzed using the coefficient of Cronbach's $\alpha$. Frequency analysis was conducted for the demographic characteristics of trainee counseling psychologists, and correlation, t-test and one-way ANOVA were also conducted. Correlation analysis was performed on the self-efficacy and interpersonal relations of trainee counseling psychologists, and the relationships of variables were found through the regression analysis.

\section{Results}

\subsection{Demographic Characteristics}

Upon examining the demographic characteristics of the research subjects, there was a higher percentage of female respondents with 56 male respondents (33.7\%) and 110 female respondents (66.3\%). In age, 40's was the highest with 56 persons (33.7\%), followed by 41 persons in their 50's (24.7\%), 38 persons in their 20's (22.9\%), and 14 persons 60's or over (8.4\%). In monthly income, more than 3 million KRW less than 3.99 million KRW was the highest with 91 persons (54.8\%), and 30 persons responded more than 2 million KRW less than 2.99 million KRW (18.1\%).

\subsection{Descriptive Statistics of Major Variables}

The major variables of trainee counseling psychologists were measured on 15 -point scale. In summary, the self-efficacy $(M=3.47)$ factor was higher than the interpersonal relations( $\mathrm{M}=3.55)$ factor, and all factors were above the mean.

\subsection{Correlation Between Variables}

Upon examining the correlation between self-efficacy and interpersonal relations of trainee counseling psychologists, the self-efficacy and interpersonal relations factors were found to have a positive correlation on a relatively high level $(\mathrm{r}=.560, \mathrm{p}<.01)$. This result implies that the variables are correlated with each correlation coefficient value at a level of statistical significance.

\subsection{Difference in Self-Efficacy According to General Characteristics}


The t-test and one-way ANOVA were conducted to confirm the difference in self-efficacy according to the general characteristics of trainee career counseling psychologists. Such results imply that self-efficacy according to general characteristics are at the same level regardless of gender and that there is a significant difference in mean between the groups for age and monthly income, with the 40's, more than 5 million KRW group having a high perception of selfefficacy.

Table. 1 Difference in interpersonal relations According to General Characteristics

\begin{tabular}{|c|c|c|c|c|c|c|}
\hline & \multirow{2}{*}{ Classification } & \multicolumn{2}{|c|}{ Levene's test } & \multirow{2}{*}{ M } & \multirow{2}{*}{ SD } & \multirow{2}{*}{$\begin{array}{r}\mathrm{t} / \mathrm{F}(\mathrm{p}) \\
\text { Scheffe }\end{array}$} \\
\hline & & $\mathrm{F}$ & $\mathrm{P}$ & & & \\
\hline \multirow{2}{*}{$\begin{array}{c}\text { Gende } \\
\text { r }\end{array}$} & Male & \multirow{2}{*}{.562} & \multirow{2}{*}{.455} & 3.44 & .46 & \multirow{2}{*}{$-2.381(.018)^{*}$} \\
\hline & Female & & & 3.61 & .45 & \\
\hline \multirow{5}{*}{ Age } & 20’s(a) & \multirow{5}{*}{3.222} & \multirow{5}{*}{.114} & 3.61 & .38 & \multirow{5}{*}{$1.543(.192)$} \\
\hline & 30’s(b) & & & 3.73 & .44 & \\
\hline & 40 ’s(c) & & & 3.55 & .46 & \\
\hline & 50’s(d) & & & 3.43 & .51 & \\
\hline & 60's and above (e) & & & 3.54 & .22 & \\
\hline \multirow{6}{*}{$\begin{array}{l}\text { Mont } \\
\text { hly } \\
\text { incom } \\
\text { e }\end{array}$} & $\begin{array}{l}\text { Less than } 1.67 \text { million } \\
\text { KRW (a) }\end{array}$ & \multirow{6}{*}{4.586} & \multirow{6}{*}{.102} & 2.85 & .02 & \multirow{6}{*}{$\begin{array}{l}7.622(.000)^{* * *} \\
\text { a<e,f,c,d,b }\end{array}$} \\
\hline & $\begin{array}{l}\text { More than } 1.68 \text { million } \\
\text { KRW - less than } 1.99 \\
\text { million KRW (b) }\end{array}$ & & & 3.35 & .30 & \\
\hline & $\begin{array}{c}\text { More than } 2 \text { million KRW } \\
\text {-less than } 2.99 \text { million } \\
\text { KRW (c) }\end{array}$ & & & 3.59 & .33 & \\
\hline & $\begin{array}{c}\text { More than } 3 \text { million KRW } \\
\text { - less than } 3.99 \text { million } \\
\text { KRW (d) }\end{array}$ & & & 3.44 & .41 & \\
\hline & $\begin{array}{c}\text { More than } 4 \text { million KRW } \\
\text { - less than } 4.99 \text { million } \\
\text { KRW (e) }\end{array}$ & & & 3.91 & .56 & \\
\hline & $\begin{array}{c}\text { More than } 5 \text { million } \\
\text { KRW (f) }\end{array}$ & & & 3.83 & .28 & \\
\hline
\end{tabular}


${ }^{*} \mathrm{p}<.05,{ }^{* * *} \mathrm{p}<.01,{ }^{* * *} \mathrm{p}<.001$

\subsection{Effect of Trainee Counseling Psychologists' Self-Efficacy on Interpersonal Relations}

Regression analysis was performed to find the effect of self-efficacy perceived by trainee counseling psychologists on their interpersonal relations. The analysis revealed that the higher the self-efficacy of trainee counseling psychologists, the higher the interpersonal relations.

Table. 2 Effect of self-efficacy on interpersonal relations

\begin{tabular}{|c|c|c|c|c|c|c|}
\hline \multirow{2}{*}{$\begin{array}{c}\text { Dependent } \\
\text { variable }\end{array}$} & \multirow{2}{*}{$\begin{array}{c}\text { Independent } \\
\text { variable }\end{array}$} & \multicolumn{2}{|c|}{$\begin{array}{c}\text { Non-standardized } \\
\text { coefficient }\end{array}$} & $\begin{array}{l}\text { Standardized } \\
\text { coefficient }\end{array}$ & \multirow{2}{*}{$\mathrm{t}$} & \multirow{2}{*}{$\begin{array}{c}\text { Significanc } \\
\text { e level }\end{array}$} \\
\hline & & B & $\begin{array}{c}\text { Standard } \\
\text { error }\end{array}$ & $\beta$ & & \\
\hline \multirow{2}{*}{$\begin{array}{l}\text { interpersonal } \\
\text { relations }\end{array}$} & Constant & 1.581 & .230 & & $6.879 * * *$ & .000 \\
\hline & self-efficacy & .568 & .066 & .560 & $8.660^{* * *}$ & .000 \\
\hline \multicolumn{7}{|c|}{$\mathrm{R}^{2}=.314$, modified $\mathrm{R}^{2}=.310$} \\
\hline \multicolumn{7}{|c|}{$\mathrm{F}=75.002, \mathrm{P}=.000$} \\
\hline$* \mathrm{p}<.05, * * \mathrm{p}<$ & $* * * \mathrm{p}<.001$ & & & & & \\
\hline
\end{tabular}

\section{Conclusion and Discussion}

This study has analyzed the difference and relationship between the self-efficacy of trainee counseling psychologists and their interpersonal relations. A discussion based on the results of the analysis is as follows.

First, upon analyzing the difference in self-efficacy according to the general characteristics of trainee counseling psychologists, no difference in mean was found in the self-efficacy according to gender at a level of statistical significance.

Second, upon analyzing the difference in interpersonal relations according to the general characteristics of trainee counseling psychologists, there was a difference in mean for interpersonal relations according to gender at a level of statistical significance.

Third, self-efficacy perceived by trainee counseling psychologists was found to have a positive effect on interpersonal relations. This implies that the higher the self-efficacy factor perceived by trainee counseling psychologists, the higher the interpersonal relations.

As discussed above, there is an increasing need ti exert positive effect on interpersonal relations, in order for early career counseling psychologists to solve various issues during the therapy process. Although studies on the counseling activity of counseling psychologists were mainly focused on case studies and the effectiveness of psychological counseling, this study is meaningful as it identified individual variables of trainee career counseling psychologists and analyzed the difference in ego-resilience and interpersonal relations according to general characteristics. Greater research is required to develop customized education programs, based on the results of this study, in order to improve the counseling outcome of trainee career counseling psychologists and to find practical measures to operate the programs systematically. 


\section{References}

[1] M. H. Kang, "A Study on Differences in Burnout and Self-Efficacy according to the Types of Counselor Perfectionism", The Graduate School of Sookmyung Women’s University, Master's Thesis. (2014)

[2] M. J. Kim, "Counselor's socio-cognitive mindfulness and counseling outcome: Testing the multiple mediation roles of counselor's self-efficacy and working alliance", The Graduate School of Ewha Womans University, Master's Thesis. (2017)

[3] Larson, L. M., Daniels, J. A. "Review of the counseling self-efficacy literature". The Counseling Psychologists, Vol. 26, No.2, pp.179-218. (1998)

[4] J. R. Jung, "The Effects of Self-compassion, Age, and Counseling Experience on Counselors`Empathy and Selfefficacy". Korean Psychological Association Conference Catalog, pp.198-198. (2016)

[5] S. H. Hong, H. R. Choi, "Contribution of Counselor Self - Efficacy and State - Anxiety to the Working Alliance in the Early Stage of Counseling". The Korean Journal of Counseling and Psychotherapy. Vol.13, No.1, pp.3149. (2001)

[6] I. H. Hwang, "The Effect of Counselor`s Self-Efficacy, Counter transference Behavior and Working Alliance on the Satisfaction of Counseling", The Korean Journal of Counseling and Psychotherapy, Vol.17, No.3, pp.547-563. (2005)

[7] J. S. Hong, "Counselor Authenticity and the Working Alliance: Mediating Effects of Counselor Relationship Skills and Client Perception of Counselors", The Korean Journal of Counseling and Psychotherapy, Vol. 29, No.3, pp.577-605. (2017)

[8] S. y. Kang, "Counselor's Self-efficacy and Counseling Outcomes : The Mediating Roles of Counselor's Counter transference and Client's Working Alliance", The Graduate School of Dankook University, Doctoral thesis. (2008)

[9] J. A. Noh. "The Effect of Counselor's characteristics on Working alliance. Focused on Attachment, Positive Thinking, Counselling Experience", The Graduate School of Yeungnam University, Master's Thesis. (2014)

\section{Authors}

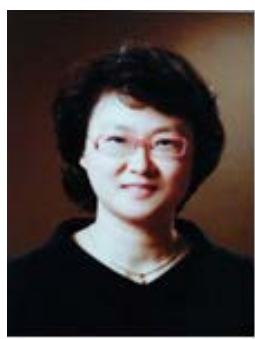

\section{Kyeng-my Song}

$2018 \sim$ present

Director of Big Dream Contents Institute of Korea Counseling Education Center 